\title{
The need for palliative care among patients with chronic diseases: a situational diagnosis in a university hospital
}

Maria da Penha Gomes Gouvea' $\mathbb{D}$

\section{Abstract}

Objective: To perform a situational diagnosis of a population hospitalized with chronic non-communicable diseases (NCD) who are potentially entitled to palliative care in a university hospital. Method: A quantitative study with document analysis was carried out. The analyzes were categorized by the following variables: baseline diagnosis, age, sex, readmission and PPS (Palliative Performance Scale) score. Results: Over two months of research among 631 hospitalized patients, 198 patients who were potentially entitled to palliative care were identified; 113 (57.1\%) of whom were older adults. Cancer was the disease with the highest incidence among the surveyed, with 95 cases, and was more recurrent in the older patient group, with 52 cases $(62.1 \%)$. Similarly, multiple hospitalizations were more prevalent in the older population, and patients diagnosed with strokes had the longest hospitalizations. Conclusion: The situational diagnosis carried out was relevant as it identified a group of patients, the majority of whom were older, who may be neglected in terms of their right to palliative care and an improved quality of death.

Keywords: Health of the Elderly. Palliative Care.

Diagnosis of Health Situation. Chronic Disease. Situational Diagnosis. 


\section{INTRODUCTION}

The worldwide discussion about the need to implement palliative care (PC) in all healthcare settings has been growing, and is based around the definition of a comprehensive and integrated approach to care. The focus, therefore, remains on the multidimensionality of patients and their families facing advanced stages of disease, conditions generated by the prognosis of a life with limitations, and physical, psychological, spiritual and emotional impacts, regardless of the environment ${ }^{1}$.

Within this new concept, PC combines the concept of interdisciplinarity with a proposal for universal access, in addition to preserving the values of compassion and commitment in care where there are situations of frailty and vulnerability. In a 2017 publication, a study found that less than $14 \%$ of the world's population has access to end-of-life PC, even though its effectiveness in helping patients and families and efficiency in providing care has already been proven ${ }^{1}$.

Among the indicators used to define the need for PC are diagnostic conditions. Patients diagnosed with one or more Chronic Noncommunicable Diseases (CNDs) are eligible for $\mathrm{PC}^{1}$. Some studies have discussed the relationship between aging and CNDs, general conditions related to the demographic and epidemiological transition, especially in relation to the older population with $\mathrm{CNDs}^{2,3}$.

As in developed countries, most deaths among older adults in Brazil are related to a CND and to cancer ${ }^{4}$. The Hospital Information System confirms that the hospitalization of older people is no longer comparable to that of younger people, and that older individuals undergo repeated hospitalizations when affected by $\mathrm{CNDs}{ }^{5}$.

CNDs are mostly disabling and lead the patient to a progressive functional decline prior to death. Thus, the development of planned actions focused on the implementation of PC in primary care, without limiting where such care is performed, is paramount ${ }^{4}$. Therefore, the relationship between population aging, the incidence of CNDs and the need for the expansion of PC should be seen as a challenge for Public Health managers at all levels of care in Brazil.
A study by Marcucci et al. identified a decline in physical and nutritional functions in primary care patients with one or more CNDs with disabling sequelae, who could have received $\mathrm{PC}^{4}$. In this context, it is important to emphasize that the implementation of PC practice focuses on protecting the independence and autonomy of the individual, as well as promoting social and family participation without neglecting social inclusion and quality of life $^{6,7}$.

There are already research groups in PC in Brazil that have sought to highlight the need for the expansion of this much needed line of care, in view of population aging and epidemiological change. These studies also underscore the need for increased financial incentives, the promotion of PC and the building of skills among health professionals across the country to minimize health disparities between regions ${ }^{8}$.

Identifying patients in need of PC by classifying their functional status and level of care needed can be performed using the Palliative Performance Scale (PPS). PPS scores guide the care needed to maintain the integrity, comfort and dignity of patients and their families, promoting quality of life until death ${ }^{1,9,10}$.

To plan the implementation of such care, however, it is necessary to identify the target population and define its characteristics. The purpose of the present study was to identify the population with CNDs admitted to a university hospital who were potentially able to receive palliative care.

\section{METHOD}

A quantitative retrospective documentary study was conducted in a university hospital in southeastern Brazil. This institution provides primary, secondary and tertiary levels of health care and is a reference center in various specialties. The total number of patients admitted to the Hospital Universitário Cassiano Antônio Moraes (the Cassiano Antônio Moraes University Hospital) (HUCAM) in the months of March and April 2015 was 631. Of these, a total of 198 records were selected through the inclusion and exclusion criteria. 
The inclusion criteria were: medical records of patients older than 18 years admitted with the diagnosis of at least one CND: AIDS, Alzheimer's, Cerebrovascular Accident/stroke (CVA), Cancer (CA), Chronic obstructive pulmonary disease (COPD), Chronic Heart failure (CHF), Chronic renal failure (CRF), Chronic liver failure (CRF). The exclusion criteria for this study were medical records of patients under 18 years of age, no diagnosis of CNDs, and patients in the Emergency, Gynecology, Obstetrics and Surgical Clinic sectors, as these departments have a high rotation, as well as patients in the Neonatal Intensive Care (NICU) and Pediatrics units, as they require different research tools and a specific approach.

The quantitative method was used in the identification and characterization of the specified population, through a data collection instrument developed by the researcher. The variables were: hospitalization unit, name, age, sex, referred from, diagnosis, date of hospitalization, readmission, outcome of patient (continued hospitalization, discharge or death) and PPS. Data collection was performed by a single evaluator.

The active search began with diagnoses of AIDS, Alzheimer's, CVA/Stroke, Cancer, Chronic Obstructive Pulmonary Disease (COPD), Chronic Heart Failure (CHF), Chronic Kidney Failure (CRF) or Chronic Liver Failure (IHC) ). After collecting personal data, the PPS scale was applied. This is a tool used to assess the degree of functionality of the individual through five categories: ambulation, activity and evidence of disease, self-care, oral intake and level of consciousness, as well as determining the level of intervention and evaluate prognosis ${ }^{11,12}$. Applying the PPS can confirm a need for Palliative Care, as well as guide decision making by identifying emerging forms of care $^{11}$. During the research period, PPS was already being used as a care tool in the institution.

From the data obtained, the situational diagnosis of patients potentially able to receive $\mathrm{PC}$ was carried out.

The study was approved by the Ethics Research Committee of the Hospital Universitário Cassiano Antônio de Moraes under process $\mathrm{N}^{\circ}$ 1.123.626.

\section{RESULTS}

According to statistics from the hospital itself, the availability of beds is between 236 and 277 , with an average occupancy of $68.61 \%$ and an average stay of around 6.59 days. The average stay was 13.49 days in the units where the study was carried out, namely the ICU, Clinical/Medical, Nephrology and Urology. Hospital statistics indicate a total of 631 hospitalizations between March and April 2015 in the sectors where this study was conducted, from which the medical records of 198 patients who met the inclusion criteria were analyzed.

Table 1 presents the characterization of the variables that compose the study. Cancer was the main diagnosis among the older population, being present in approximately half (48\%) of the analyzed medical records. Of the 95 patients aged 60-79 years, $53 \mathrm{had}$ some type of cancer. If the older group is considered as all those over 60 years old, then older individuals represented $57.1 \%$ of the studied cases. There was a majority of men in the sample.

Most patients, $64.1 \%$, had been admitted to the same hospital more than once. In the analysis of the crossing of the data found in the Outcome and PPS score variables, it was found that none of the patients with a PPS score between 70 and 100 died, and of the 57 patients in this category, 52 were discharged.

However, in the group of patients with PPS scores between 40 and 60 , one patient died on the same day as hospitalization. Of the most severe patients, with PPS scores between 10 and 30, 14 were discharged during the survey. Most of the deaths in the surveyed group, 35 (97.2\%), were among patients with a PPS score of between 10 and 30 .

Table 2 shows that older adults had a longer average length of stay (27, sd \pm 27$)$ and (25, sd \pm 19$)$. The average length of stay of patients over 60 years old (27 days) represents almost twice the average hospital stay, based on hospital statistics.

Among the diagnoses sought in the research, the results of Table 3 show that CA had the highest incidence among respondents, with 95 cases, being more recurrent among older adults, with 59 cases 
(62.1\%). Of the 18 AIDS patients, $14(77.8 \%)$ were 30 to 59 years old.

According to Table 4, of the diagnoses that caused multiple hospitalizations, most patients in all categories have already had previous hospitalizations in this hospital. Hospitalizations were more recurrent in patients with $\mathrm{CHF}$. Among all the age groups analyzed, the highest percentage of readmission was among older patients, and among the 113 such individuals, four $(65.4 \%)$ had already been admitted to this hospital due to the same disease.

Table 1. Characterization of the variables studied to elaborate the situational diagnosis of hospitalized patients $(n=198)$ in a university hospital in Vitória, Espírito Santo, 2015.

\begin{tabular}{|c|c|}
\hline Category & $\mathrm{n}(\%)$ \\
\hline \multicolumn{2}{|l|}{ Diagnosis } \\
\hline Aids & $18(9.1)$ \\
\hline Alzheimer's & $3(1.5)$ \\
\hline Cerebral Vascular Accident/Stroke & $5(2.5)$ \\
\hline Cancer & $95(48.0)$ \\
\hline Chronic obstructive pulmonary disease & $18(9.1)$ \\
\hline Chronic Heart Failure & $21(10.6)$ \\
\hline Chronic Liver Failure & $20(10.1)$ \\
\hline Chronic Kidney Failure & $18(9.1)$ \\
\hline \multicolumn{2}{|l|}{ Age range (years) } \\
\hline Up to 29 & $10(5.1)$ \\
\hline 30 to 59 & $75(37.9)$ \\
\hline 60 to 79 & $95(48.0)$ \\
\hline 80 or older & $18(9.1)$ \\
\hline \multicolumn{2}{|l|}{ Sex } \\
\hline Female & $81(40.9)$ \\
\hline Male & $117(59.1)$ \\
\hline \multicolumn{2}{|l|}{ Readmission } \\
\hline No & $71(35.9)$ \\
\hline Yes & $127(64.1)$ \\
\hline Remained in hospital & $29(14.6)$ \\
\hline Death & $36(18.2)$ \\
\hline \multicolumn{2}{|l|}{ PPS (Palliative Performance Scale) } \\
\hline 10 - Completely bedbound & $12(6.1)$ \\
\hline 20 - Completely bedbound & $20(10.1)$ \\
\hline 30 - Completely bedbound & $30(15.2)$ \\
\hline $40-$ Bedbound most of the time & $22(11.1)$ \\
\hline $50-$ Bedbound or lying down most of the time & $24(12.1)$ \\
\hline $60-$ Reduced & $33(16.7)$ \\
\hline 70 - Reduced & $27(13.6)$ \\
\hline 80 - Complete & $21(10.6)$ \\
\hline 90 - Complete & $7(3.5)$ \\
\hline 100 - Complete & $2(1.0)$ \\
\hline
\end{tabular}

Source: Author's own (2015). 
Table 2. Length of stay x age range and diagnosis of hospitalized patients $(n=198)$ in a university hospital in Vitória, Espírito Santo, 2015.

\begin{tabular}{|c|c|c|c|c|c|c|c|}
\hline \multirow[b]{2}{*}{ Category } & \multicolumn{7}{|c|}{ Time (days) } \\
\hline & Minimum & Percentile 25 & Median & Percentile 75 & Maximum & Mean & $\begin{array}{l}\text { Standard } \\
\text { deviation }\end{array}$ \\
\hline \multicolumn{8}{|c|}{ Age range (years) } \\
\hline Up to 29 & 1.0 & 6.0 & 9.5 & 21.0 & 64.0 & 16.3 & 18.5 \\
\hline 30 to 59 & 1.0 & 9.0 & 16.0 & 24.0 & 75.0 & 18.7 & 13.5 \\
\hline 60 to 79 & 1.0 & 10.0 & 19.0 & 36.0 & 193.0 & 27.1 & 27.0 \\
\hline 80 or more & 2.0 & 12.0 & 20.5 & 33.0 & 67.0 & 24.8 & 19.1 \\
\hline \multicolumn{8}{|l|}{ Diagnosis } \\
\hline Aids & 10.0 & 15.0 & 21.0 & 26.0 & 48.0 & 22.3 & 10.4 \\
\hline Alzheimer's & 23.0 & 23.0 & 23.0 & 40.0 & 40.0 & 28.7 & 9.8 \\
\hline $\mathrm{CVA}^{*}$ & 8.0 & 22.0 & 33.0 & 75.0 & 100.0 & 47.6 & 38.5 \\
\hline Cancer & 1.0 & 7.0 & 14.0 & 30.0 & 193.0 & 21.5 & 25.3 \\
\hline $\mathrm{CPOD}^{* *}$ & 5.0 & 18.0 & 21.0 & 32.0 & 52.0 & 23.8 & 11.5 \\
\hline CHF*** & 2.0 & 9.0 & 13.0 & 25.0 & 58.0 & 18.6 & 15.0 \\
\hline $\mathrm{CLF}^{\mathrm{a}}$ & 1.0 & 10.5 & 14.5 & 22.5 & 73.0 & 18.7 & 15.8 \\
\hline$C K F^{b}$ & 5.0 & 19.0 & 27.5 & 51.0 & 82.0 & 34.7 & 22.7 \\
\hline
\end{tabular}

Source: Author's own (2015).

*CVA: Chronic Vascular Accident/Stroke; ${ }^{* * C O P D}$ : Chronic Obstructive Pulmonary Disease; ***CHF: Chronic Heart Failure; ${ }^{\text {aCLF}}$ : Chronic Liver Failure; ${ }^{\mathrm{b}} \mathrm{CKF}$ : Chronic Kidney Failure.

Tabela 3. Diagnosis $x$ age range in patients hospitalized at a university hospital in Vitória, Espírito Santo between March and April 2015.

\begin{tabular}{lllll}
\hline & & & Age range (years) & \\
Diagnosis & Up to 29 & 30 to 59 & 60 to 79 & 80 or more \\
& $\mathrm{n}(\%)$ & $\mathrm{n}(\%)$ & $\mathrm{n}(\%)$ & $\mathrm{n}(\%)$ \\
\hline Aids & $3(16.7)$ & $14(77.8)$ & $1(5.6)$ & $0(0.0)$ \\
Alzheimer's & $0(0.0)$ & $0(0.0)$ & $2(66.7)$ & $1(33.3)$ \\
CVA & $0(0.0)$ & $2(40.0)$ & $2(40.0)$ & $1(20.0)$ \\
Cancer & $4(4.2)$ & $32(33.7)$ & $53(55.8)$ & $6(6.3)$ \\
CPOD* & $0(0.0)$ & $9(50.0)$ & $6(33.3)$ & $3(16.7)$ \\
CHF** & $1(4.8)$ & $5(23.8)$ & $11(52.4)$ & $4(19.0)$ \\
CLF*** & $2(10.0)$ & $11(55.0)$ & $7(35.0)$ & $0(0.0)$ \\
${ }^{a}$ CKF & $0(0.0)$ & $2(11.1)$ & $13(72.2)$ & $3(16.7)$ \\
\hline
\end{tabular}

Source: Author's Own (2015).

CVA: Chronic Vascular Accident/Stroke; *COPD: Chronic Obstructive Pulmonary Disease; ${ }^{*}$ CHF: Chronic Heart Failure; $* * * C L F$ : Chronic Liver Failure; ${ }^{a} \mathrm{CKF}$ : Chronic Kidney Failure. 
Table 4. Readmission $\mathrm{x}$ diagnosis $\mathrm{x}$ age range in patients admitted to a university hospital in Vitória, Espírito Santo in March and April 2015.

\begin{tabular}{lll}
\hline & \multicolumn{2}{c}{ Readmission } \\
Category & No & Yes \\
& $\mathrm{n}(\%)$ & $\mathrm{n}(\%)$ \\
\hline Diagnosis & & \\
Aids & $4(2.2)$ & $14(77.8)$ \\
Alzheimer's & $1(33.3)$ & $2(66.7)$ \\
CVA* & $2(40.0)$ & $3(60.0)$ \\
Cancer & $40(42.1)$ & $55(57.9)$ \\
CPOD ${ }^{* *}$ & $7(38.9)$ & $11(61.1)$ \\
CHF*** & $4(19.0)$ & $17(81.0)$ \\
CLF & $6(30.0)$ & $14(70.0)$ \\
CKF & $7(38.9)$ & $11(61.1)$ \\
\hline Age range (years) & & $6(60.0)$ \\
Up to 29 & $4(40.0)$ & $47(62.7)$ \\
30 to 59 & $28(37.3)$ & $60(63.2)$ \\
60 to 79 & $35(36.8)$ & $14(77.8)$ \\
80 or more & $4(22.2)$ & \\
\hline
\end{tabular}

Source: Author's Own (2015).

*CVA: Chronic Vascular Accident/Stroke; ${ }^{* * C O P D}$ : Chronic Obstructive Pulmonary Disease; $* * * C H F:$ Chronic Heart Failure; ${ }^{*}$ CLF: Chronic

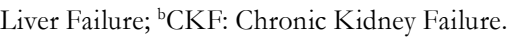

\section{DISCUSSION}

The representativeness of the older population in the research, with 113 such individuals $(57.1 \%)$, corroborates the results of studies ${ }^{4,13-15}$ that demonstrate the predominance of older patients among those occupying hospital beds. Functional disability, vulnerability, and limitations caused by CNDs require an interdisciplinary perspective on new public health practices, as the need for prevention, care, and rehabilitation can directly reflect public spending ${ }^{4,13-15}$.

According to the findings, cancer was prominent in the results achieved, afflicting $48 \%$ of patients, of whom $62.1 \%$ were older adults, results confirmed by data from the National Cancer Institute ${ }^{16}$, which confirm the increased incidence of cancer after 60 years of age.

In addition to the physical changes that generate limitations in daily life, the various realities experienced by younger individuals who develop a chronic disease are transformative and determinant in terms of social exclusion and the loss of functionality within the process of living with illness. This process limits human beings from projecting or planning the future, dulling their outlook and inhibiting questions about their illness ${ }^{17}$.

The values of the PPS scale provide significant points for consideration, as identifying prognoses may indicate the need for intensified care ${ }^{10,11}$. In this study, patients with a PPS score of 70 (13.6\%) had reduced ambulation and may have had their social lives put at risk, facing limitations in work and significant illness. However, they may still have been totally independent in self-care, have a complete level of consciousness, and have their intake affected, indicating the beginning of the intensification of their functional decline ${ }^{11}$. Patients with a PPS score below 70 should be approached by the palliative care team, with the aim of promoting the knowledge of disease progression, the maintenance of autonomy, presentation of care plans and advanced guidelines ${ }^{11,13}$.

Interestingly, the $33(16.7 \%)$ patients with a PPS score of 60 were at a high risk of "social death" and had reduced ambulation, and may have been incapable of hobbies or housework ${ }^{1,11,13}$. A patient 
with a score below 60 denotes reduced intake and a complete level of consciousness or periods of evident confusion, vulnerability and loss of autonomy, with the manifestation of significant disease progression, leading to the need for occasional assistance ${ }^{1,1}$.

The 46 patients $(23.2 \%)$ with scores of 40 and 50 on the PPS scale were bedridden or spent most of the time sitting or lying down, with the extent of their disease manifested in the incapacity for any work or activity. These patients could no longer maintain their independence, requiring almost total assistance in daily activities. In addition to their decreased levels of consciousness, ranging from lucid to confused, these patients demonstrate a steep decline in almost all categories explored by PPS. The scale shows that patients with scores below 60 had a prognosis of up to 207 days $^{11,13}$.

Among the 30 patients with a score of 30 were those who were completely bedridden, incapacitated for any activity and had an extensive stage disease and were totally dependent on self-care, but maintained normal or reduced intake and level of consciousness ranging from complete to drowsiness or confusion. Patients with PPS scores below 30 had a high mortality rate and intensive and immediate care needs ${ }^{11,13}$. When estimating a patient's survival, sufficient time should be allowed to guide interventions through the definition of a care plan, allowing daily monitoring of the progression of the disease ${ }^{11}$.

However, patients with PPS scores of between 10 and 20 already had a need for a high level of care, being fully bedridden and totally dependent on self-care, unable to perform any activities, and presenting drowsiness, confusion or coma. Of the $62(31.4 \%)$ patients who had PPS scores of between 10 and 30, 35 unfortunately died during the survey. Predicting the life of the patient is essential for planning interventions within PC. A risk and benefit analysis of treatment may be based on prognosis. The PPS scale demonstrably serves the purpose of predicting patient survival time and guiding care ${ }^{11}$.

The result of the present study confirms that hospitalization time increases with age ${ }^{18}$, with the age group from 60 to 79 years old having the longest average length of stay. Concomitant with the increasing number of hospitalizations in the current context, an increase in the number of deaths in Brazilian hospitals has been observed, but in countries where access to palliative care is easier, deaths tend to happen at home or in a care facility ${ }^{1,4,5}$.

Associating aging and loss of autonomy with the consecutive hospitalizations caused by CNDs underlines the urgency of implementing new lines of care, such as PC. The intensification of care becomes paramount, especially for older adults, as these individuals tend to verbalize their complaints less and less ${ }^{10}$.

On the other hand, while it is known that prolonged hospitalizations and intensive care units represent a notorious and growing public expenditure in health ${ }^{18}$, expanding PC practices in the current public health scenario may represent the provision of broad and ideal care to the older population, respecting their multidimensionality ${ }^{13}$. Discussions about the quality of services, criticism of the qualifications of professionals and poor quality of user care, signal the need for strategies to improve the management and performance rates of most Brazilian hospitals ${ }^{10,18}$.

A study on Public Health entitled the Principle of efficiency as a foundation for publicpolicy and the effectiveness of the right to healt $h^{19}$, supports the idea that efficiency can be achieved through timely and positive development in the health sector and that legality and morality characterize good management.

Using variables similar to the present study, the analysis of the length of hospitalization of older adults in a teaching hospital indicated an increase of chronic diseases and their complications, also emphasizing that CNDs are the most common causes of hospitalization among older patients. In this context, it is worth asking if increased life expectancy contributes to repeated and long hospitalizations ${ }^{20}$.

\section{CONCLUSION}

The situational diagnosis carried out indicated that a significant number of hospitalized patients were candidates for PC. The older population made 
up the majority of the sample, and it was confirmed that such individuals with CNDs face readmissions and prolonged hospitalizations. The findings also reveal the need for a differentiated approach, since the predominant diagnosis in the study was cancer, a rapidly evolving disease among CNDs.

Thus, it is well known that implementing palliative care involves the need for a team with technical and multidisciplinary knowledge, with a multidimensional human perception capacity, so that interventions are timely and decisions are made to promote the quality of life of the patient. The inclusion and standardization of palliative care improves "quality of death", which could represent a huge gain for the quality of the Brazilian public health system.

The effectiveness of the PPS was proven by indicating the urgency of the need for PC, as almost

\section{REFERENCES}

1. Gómez-Batiste X, Connor S, editors. Building Integrated Palliative Care Programs and Services [Internet]. Catalonia: Liberdúplex; 2017 [acesso em 10 abril 2019]. Disponível em: http://kehpca.org/wpcontent/uploads/Go $\% \mathrm{CC} \% 81 \mathrm{mez}-\mathrm{Batiste}-\mathrm{X}$-ConnorS-Eds.-Building-Integrated-Palliative-Care-Programsand-Services.-2017-b.pdf

2. Madureira RMS, Zandonade E, Maciel PMA. Saúde pública em Vitória: vários olhares. Vitória: Gráfica e Editora Aquarius; 2012.

3. Oliveira M, Veras R, Cordeiro H. A saúde suplementar e o envelhecimento após 19 anos de regulação: onde estamos? Revi Bras Geriatr Gerontol [Internet]. 2017 [acesso em 10 abr. 2019];20(5):624-33. Disponível em: http://www. scielo.br/scielo.php?script $=$ sci_arttext\&pid=S180998232017000500624\&lng=en\&nrm=iso

4. Marcucci FCI, Perilla AB, Brun MM, Cabrera MAS Identificação de pacientes com indicação de Cuidados Paliativos na Estratégia Saúde da Família: estudo exploratório. Cad Saúde Colet [Internet]. 2016 [acesso em 11 abr. 2019];24(2):145-52. Disponível em: http://www. scielo.br/scielo.php?script=sci_arttext\&pid=S1414462X2016000200145\&lng=en\&nrm=iso all patients with a critical score died during the study period.

Given this scenario, it is emphasized that the implementation of palliative care should be recommended at diagnosis, thus maintaining curative treatment combined with the interventions required at the beginning of palliative care. In this way, depending on the evolution of the disease, PC can override curative medicine until such time as only such care can meet the emotional, social and spiritual physical needs of the patient and their family members, extending even to the mourning phase.

One limitation of this study is the momentary unavailability of medical records, the absence of data in such records, and the fact they are printed rather than electronic.

Edited by: Tamires Carneiro Oliveira Mendes
5. Brasil. Ministério da Saúde. Departamento de Informática do SUS- Datasus [Internet]. Rio de Janeiro; 2015. Informações de saúde para informações de 2015; [acesso em 11 abr. 2017]; [ 2 telas]. Disponível em http://www.datasus.gov.br

6. Alencar VA. Contribuições da internação domiciliar para promover a desospitalização e prevenir reospitalização no âmbito do SUS [Dissertação na Internet]. Brasília, DF: Universidade de Brasília; 2013 [acesso em 11 abr. 2019]. Disponível em: http:// repositorio.unb.br/handle/10482/15227

7. Galvão CR, Pinochet LHC, Vieira MA, Miquelão R. Análise de indicadores de monitoramento de pacientes portadores de doenças crônicas: estratégia de redução de custos. Mundo Saúde [Internet]. 2011 [acesso em 11 abr. 2019];35(4):427-37. Disponível em: http://bvsms.saude.gov.br/bvs/artigos/analise_ indicadores_monitoramento_pacientes_doencas_ cronicas.pdf

8. Nickel L, Oliari L, Vesco SNP, Padilha MI. Grupos de pesquisa em cuidados paliativos: a realidade brasileira de 1994 a 2014. Esc Anna Nery [Internet]. 2016 [acesso em 11 abr. 2019];20(1):70-6. Disponível em: http://www.scielo.br/scielo.php?script=sci_ arttext\&pid=S1414-81452016000100070\&lng=en\& nrm $=$ iso 
9. Beduschi FM, Alcântara CO, Pereira FM, Pinheiro TCE, Cintra MTG, Bicalho MAC. Cuidados paliativos no atendimento público hospitalar: a importância do atendimento de pacientes jovens. Rev Soc Bras Clin Med [Internet]. 2018 [acesso em 23 set. 2019];16(2):80-4. Disponível em: http://docs.bvsalud. org/biblioref/2018/09/913364/16280-84.pdf

10. Cabianca Cam, Menegheti GG, Bernardi ICP, Gurgel SJT. Comparação entre Escala de Performance de Karnofsky e Escala de Avaliação de Sintomas de Edmonton como determinantes na assistência paliativa. Rev Soc Bras Clin Med [Internet]. 2017 [acesso em 23 set. 2019];15(1):25. Disponível em: http://docs.bvsalud.org/ biblioref/2017/04/833045/2-5-2.pdf

11. Creber RM, Russel D, Dooley F, Jordan L, Baik D, Goyal R, et al. Use of Palliative Performance Scale to estimate survival among home hospice patients with heart failure. ESC Heart Fail [Internet]. 2019 [acesso em 23 set. 2019];6:371-78. Disponível em: https:// www.ncbi.nlm.nih.gov/pmc/articles/PMC6437549/

12. Brasil. Academia Nacional de Cuidados Paliativos. Manual de cuidados paliativos. $2^{\mathrm{a}} \mathrm{ed}$. Rio de Janeiro: Diagraphic; 2012.

13. Cruz RR, Beltrame V, Dallacosta FM. Envelhecimento e vulnerabilidade: análise de 1.062 idosos. Rev Bras Geriatr Gerontol [Internet]. 2019 [acesso em 18 nov. 2019];22(3):e180212 [6 p.]. Disponível em http://www. scielo.br/scielo.php?script $=$ sci_arttext\&pid $=$ S180998232019000300204\&lng=pt\&nrm=iso

14. Rodrigue MMS, Alvarez AM, Rauch KC. Tendência das internações e da mortalidade de idosos por condições sensíveis à atenção primária. Rev Bras Epidemiol [Internet]. 2019 [acesso em 23 set. 2019];22:e190010 [11 p.]. Disponível em: http://www. scielo.br/scielo.php?script=sci_arttext\&pid=S1415790X2019000100403\&lng=pt\&nrm=iso
15. Santos SL, Turra C, Noronha K. Envelhecimento populacional e gastos com saúde: uma análise das transferências intergeracionais e intrageracionais na saúde suplementar brasileira. Rev Bras Estud Popul [Internet]. 2018 [acesso em 23 set. 2019];35(2):e0062 [30p.]. Disponível em: http://www. scielo.br/scielo.php?script=sci_arttext\&pid=S010230982018000200155\&lng=en\& $\mathrm{nrm}=$ iso

16. Brasil. Ministério da Saúde. Estimativa 2014 Incidência do câncer no Brasil/ Instituto Nacional de Câncer José Alencar Gomes da Silva [Internet]. Rio de Janeiro: INCA; 2014 [acesso em 13 maio 2015]. Disponível em: http://www.inca.gov.br/estimativa/2014/sintese-deresultados-comentarios.asp

17. Machado LRC, Car MR. A dialética da vida cotidiana de doentes com insuficiência renal crônica: entre o inevitável e o casual. Rev Esc Enferm USP [Internet]. 2003 [acesso em 13 maio 2019];37(3):27-35. Disponível em: http://www.scielo.br/pdf/reeusp/v37n3/04.pdf

18. Souza LF, Misko MD, Silva L, Poles K, Santos MR, Bousso RS. Morte digna da criança: percepção de enfermeiros de uma unidade de oncologia. Rev Esc Enferm USP [Internet]. 2013 [acesso em 11 abr. 2019];47(1):30-70. Disponível em: http://www.scielo.br/scielo.php?script $=$ sci_ arttext\&pid=S0080-62342013000100004

19. Lima JPK, Souza LDF. Princípio da eficiência como fundamento para a política pública e a efetividade do direito à saúde. Em Tempo [Internet]. 2014 [acesso em 23 set. 2019];13:252-66. Disponível em: file://C:/Users/mariagouvea.hucam/ Downloads/461-1-1683-1-10-20141215.pdf

20. Rodrigues CC, Ribeiro RCHM, Cesarino VB, Bertolin DC, Ribeiro RM, Oliveira MP, et al. Idosos internados em um hospital escola: características clínicas e desfechos. Rev Enferm UFPE On Line [Internet]. 2017 [acesso em 23 set. 2019];11(12):4938-45. Disponível em: https://periodicos.ufpe.br/revistas/revistaenfermagem/ article/view/24046/25312 